\title{
Early Landscape Performance of 20 Field-Grown Birch Genotypes at Two Locations in Arkansas, U.S. and Response to Irrigation
}

\author{
Mengmeng Gu, James A. Robbins, and Curt R. Rom
}

\begin{abstract}
Twenty birch genotypes were planted in the field in April 2002 to evaluate their survival and growth at Fayetteville and Hope, Arkansas, U.S., and to evaluate their response to two irrigation regimes at Fayetteville. After four growing seasons, the overall tree survival was $62 \%$ and $30 \%$ at Fayetteville and Hope, respectively. Betula pendula 'Trost's Dwarf', B. ermanii, and B. albosinensis were among genotypes with the lowest survival at both locations. Betula populifolia, B. nigra 'BNMTF', B. nigra 'Cully', and B. × 'Royal Frost' had greater survival after four growing seasons than the other birch genotypes investigated. Betula nigra 'BNMTF' and B. nigra 'Cully' were taller and had greater trunk diameter than the other surviving birch genotypes at both locations after four growing seasons. At the end of 2005, B. utilis var. jacquemontii was the shortest and had the smallest trunk diameter among the 18 surviving genotypes at Fayetteville, and B. papyrifera 'Uenci', B. populifolia 'Whitespire', B. maximowicziana, and B. lenta were the shortest and had the smallest trunk diameter among the 13 surviving genotypes at Hope. At Fayetteville, B. nigra and B. davurica had the greatest annual change in tree height in both 2004 and 2005, and $B$. davurica was among genotypes having the greatest annual change in trunk diameter in 2002, 2004, and 2005. At Hope, B. papyrifera had the greatest annual change in tree height in both 2004 and 2005, and B. davurica had the greatest annual change in trunk diameter in 2004. In 2005, annual change was not significant among birch genotypes at Hope. At Fayetteville, water-stress treatment reduced final tree height and trunk diameter in birch trees.
\end{abstract}

Key Words. Growth; irrigation regime; survival.

The birches (Betula L.), especially white-barked genotypes, are popular woody plants. Their ornamental characteristics include pendulous catkins, yellow fall foliage, and peeling bark featuring colors from reddish brown to white (Furlow 1990). The origins of most birch genotypes are the temperate, boreal, and arctic zones of North America, Europe, and Asia (Krussmann 1984; Furlow 1990; Atkinson 1992; Farrar 1995).

High air temperatures are often a limiting factor in a plant's adaptability and productivity and there is considerable variation in high temperature tolerance among birch genotypes (Ranney and Peet 1994). Water deficit often limits tree growth in urban landscapes (Zwack and Graves 1998; Ladjal et al. 2000). Bronze birch borer, Agrilus anxius Gory, is a major problem causing birch dieback in urban landscapes (Santamour 1999). In many birch species under water stress, rhododendrol hydrolyzed from rhododendrin may act as a stimulant to its oviposition (Santamour et al. 1997). Waterdeficit tolerance among birch genotypes was observed under controlled conditions (Ranney et al. 1991). Except for anecdotal observations, no research data are available on field performance of birch genotypes or the effect of irrigation regimes on field-grown birch genotypes in the southern United States. Intensive landscape evaluation of birch genotypes in the southern United States would provide useful information for the ornamental industry and homeowners.

The objectives of this study were to evaluate survival and growth of 20 birch genotypes at two locations in Arkansas representing two USDA cold hardiness zones and two AHS heat zones, Fayetteville (USDA cold hardiness zone 7; AHS heat zone 7) and Hope (USDA cold hardiness zone 8; AHS heat zone 8), and to evaluate their response to two irrigation regimes at Fayetteville. The hypothesis was that the survival and growth of birch genotypes under higher temperature and nonirrigation conditions would not be as good as under cooler and irrigated conditions.

\section{MATERIALS AND METHODS}

Of the 20 birch genotypes evaluated in the study, 10 are native North American species or their selections, nine are Euro-Asian origin species or their selections, and one hybrid 
$[B . \times$ 'Royal Frost' $=$ B. populifolia 'Whitespire' $\times$ B. $\times$ 'Crimson Frost'; $B . \times$ 'Crimson Frost' $=$ B. platyphylla var. szechuanica (Schneid.) Rehd $\times$ B. pendula 'Purpurea'] has both North American and Euro-Asian heredity (Table 1). The 11 species typically grow in the range of USDA cold hardiness zone 2 to zone 6 .

One-year-old rooted cuttings or bare-root plants obtained from commercial nurseries were potted in $3.8 \mathrm{~L}$ (1 gal) pots with SunGro SB300 Universal Mix (Pine Bluff, AR) in Winter 2001. Three of the genotypes were obtained from two different nursery sources (B. nigra-Evergreen N. and J. F. Schmidt \& Son Co.; B. nigra 'Cully' Heritage ${ }^{\circledR}$ - Heritage Seedlings Inc. and Forest Hills N.; B. pendula-Meadow Lake N. and J.F. Schmidt \& Son Co.). Container plants were grown in an outdoor lathe house until they were planted in the field plots.

Trees were planted on 12 and 5 April 2002 at the Arkansas Agriculture Research and Extension Center, Fayetteville (latitude: $36.1 \mathrm{~N}$; longitude: $94.1 \mathrm{~W}$; altitude: $427 \mathrm{~m} / 1400 \mathrm{ft}$; USDA cold hardiness zone 7; AHS heat zone 7) and Southwest Research and Extension Center, Hope (latitude: 33.7N; longitude: $93.6 \mathrm{~W}$; altitude: $106 \mathrm{~m} / 350 \mathrm{ft}$; USDA cold hardiness zone 8; AHS heat zone 8), Arkansas, respectively. The soil type was Captina silt loam $(\mathrm{pH}=6.2)$ at the Fayetteville site and Bowie fine sandy loam $(\mathrm{pH}=5.5)$ at the Hope site. Trees were planted $2.5 \mathrm{~m}(8 \mathrm{ft})$ apart in a row and the distance

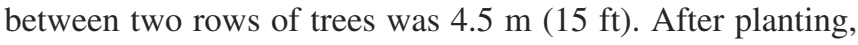
rows were mulched with hardwood chips to a depth of $10 \mathrm{~cm}$ (4 in). Trees were fertilized with $10 \mathrm{~g} 15 \mathrm{~N}-2 \mathrm{P}-8 \mathrm{~K}$ fertilizer (Harrell's Fertilizer, Lakeland, FL) with micronutrients after planting and with $10 \mathrm{~g} 45 \mathrm{~N}-0 \mathrm{P}-0 \mathrm{~K}$ (Oakley Fertilizer, North Little Rock, AR) annually from 2003 to 2005 as suggested by the soil analysis.

At Fayetteville, all trees were irrigated for 2 hours per day and 3 days per week from May to September using a drip system with Rainbird ${ }^{\circledR}$ EM-L20 SSP Lady Bug emitters

Table 1. Characteristics and origin of 20 birch genotypes evaluated at Fayetteville and Hope, Arkansas.

\begin{tabular}{|c|c|c|c|c|c|}
\hline Genotypes & Common name ${ }^{z}$ & Origin $^{z}$ & $\begin{array}{l}\text { USDA cold } \\
\text { hardiness } \\
\text { zone }^{\mathrm{z}}\end{array}$ & $\begin{array}{l}\text { Natural } \\
\text { height }(\mathrm{m})^{\mathrm{z}}\end{array}$ & Nursery source \\
\hline B. albosinensis Burkill. & Chinese red birch & W. and SW. China & 6 & $18-25$ & Heritage (OR) \\
\hline B. alleghaniensis Britton & Yellow birch & Eastern N. America & 2 & $20-30$ & Lawyer (MT) \\
\hline B. davurica Pall. & Black birch & N. China, Korea & 5 & $5-9$ & Forestfarm (OR) \\
\hline B. ermanii Cham. & Erman's birch & NE. Asia, Japan, Korea & 6 & 20 & Meadow Lake (OR) \\
\hline B. lenta $\mathrm{L}$. & Sweet birch & Eastern N. America & 3 & 25 & Lawyer (MT) \\
\hline B. maximowicziana Regel. & Monarch birch & Japan & 5 & 30 & Lawyer (MT) \\
\hline B. nigra $\mathrm{L}$. & River birch & Eastern U.S. & 5 & $12-20$ & $\begin{array}{l}\text { Evergreen (WI); } \\
\text { Schmidt (OR) }\end{array}$ \\
\hline B. nigra 'BNMTF' Dura-Heat ${ }^{\mathrm{TM}}$ & Dura-Heat birch & - & 4 & - & Moon (GA) \\
\hline B. nigra 'Cully' Heritage ${ }^{\circledR}$ & Heritage birch & - & 4 & - & $\begin{array}{l}\text { Heritage (OR); } \\
\text { Forest Hill (SC) }\end{array}$ \\
\hline $\begin{array}{l}\text { B. papyrifera Marsh. } \\
\text { B. papyrifera 'Renci' }\end{array}$ & Paper birch & N. America & 4 & 30 & Schmidt (OR) \\
\hline Renaissance Reflection $^{\mathrm{TM}}$ & $\begin{array}{l}\text { Renaissance Reflection } \\
\text { paper birch }\end{array}$ & - & - & - & Evergreen (WI) \\
\hline \multicolumn{6}{|l|}{ B. papyrifera 'Uenci' } \\
\hline Renaissance Upright $^{\mathrm{TM}}$ & $\begin{array}{l}\text { Renaissance Upright paper } \\
\text { birch }\end{array}$ & - & - & - & Evergreen (WI) \\
\hline $\begin{array}{l}\text { B. pendula Roth. } \\
\text { Schmidt (OR) }\end{array}$ & European white birch & Europe, Asian Minor & 2 & 20 & Meadow Lake (OR); \\
\hline B. pendula 'Trost's Dwarf' & Trost's Dwarf birch & - & - & 1 & Briggs (WA) \\
\hline $\begin{array}{l}\text { B. pendula 'Laciniata' } \\
\text { B. platyphylla Sukatchev. }\end{array}$ & Laciniata birch & - & - & 12 & Briggs (WA) \\
\hline 'Fargo' Dakota Pinnacle ${ }^{\mathrm{TM}}$ & $\begin{array}{l}\text { Dakota Pinnacle Manchurian } \\
\text { birch }\end{array}$ & - & 5 & $10-20$ & Meadow Lake (OR) \\
\hline B. populifolia Marsh. & Gray birch & Eastern N. America & 3 & $10-20$ & Forestfarm (OR) \\
\hline B. populifolia 'Whitespire' & Whitespire birch & - & - & - & Briggs (WA) \\
\hline B. $\times$ 'Royal Frost' & Royal Frost birch & - & - & - & Evergreen (WI) \\
\hline $\begin{array}{l}\text { B. utilis D. Don var. } \\
\text { jacquemontii (Spach.) Winkl. }\end{array}$ & $\begin{array}{l}\text { White-barked Himalayan } \\
\text { birch }\end{array}$ & W. Himalaya & 6 & - & Briggs (WA) \\
\hline
\end{tabular}

${ }^{\mathrm{z}}$ From Krussmann (1984) and Dirr (1998). 


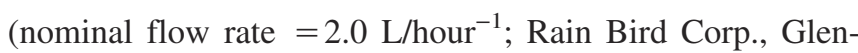
dora, CA) in 2002. There was one emitter for each tree and emitters were placed close to the tree trunk. Water was collected from randomly selected emitters and the average flow

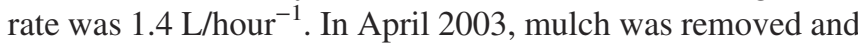
all rows were covered with $1.2 \mathrm{~m}(4 \mathrm{ft})$ wide plastic film (4 mil) to limit precipitation infiltration to the soil before being remulched with hardwood chips to a depth of $10 \mathrm{~cm}$ (4 in). In May 2003, soil tensiometers (Irrometer Company, Inc., Riverside, CA) were installed at $30 \mathrm{~cm}$ (12 in) depth close to the trunk of two randomly selected birch trees within each row at Fayetteville. Tensiometers were removed after each growing season. In April 2004, tensiometers were installed at $30 \mathrm{~cm}$ (12 in) depth at a distance of $30 \mathrm{~cm}$ (12 in) from the trunks of three randomly selected birch trees within each row. In April 2005, tensiometers were installed at $30 \mathrm{~cm}$ (12 in) depth at a distance of $50 \mathrm{~cm}$ (20 in) from the trunks of four randomly selected birch trees within each row. Tensiometer readings were recorded daily.

Two irrigation regimes were applied to the Fayetteville field plot from 2003 to 2005: (1) watered (WW): four rows of trees were watered to keep the average tensiometer readings between 0 and $10 \mathrm{KPa}(10 \mathrm{cb})$; and (2) water-stressed (WS); the other four rows of trees were watered after the average tensiometer readings exceeded $40 \mathrm{KPa}(40 \mathrm{cb})$.

At Hope, tree rows were not covered with plastic film but mulched and fertilized in a manner similar to Fayetteville. From 2002 to 2005, all trees were irrigated for 2 hours per day and 3 days per week from May to September, which was similar to the irrigation treatment for WW trees at Fayetteville.

Weather data were obtained from both Fayetteville and Hope locations from 2002 to 2005 (Tables 2 and 3). The average annual high and low temperatures during the 4 years were $20^{\circ} \mathrm{C}\left(68^{\circ} \mathrm{F}\right)$ and $9^{\circ} \mathrm{C}\left(48^{\circ} \mathrm{F}\right)$ at Fayetteville, which were $3^{\circ} \mathrm{C}\left(37^{\circ} \mathrm{F}\right)$ and $1^{\circ} \mathrm{C}\left(34^{\circ} \mathrm{F}\right)$ lower than those at Hope, respectively. The average annual precipitation during that period was $97.9 \mathrm{~cm}$ (39.2 in) at Fayetteville and $112.3 \mathrm{~cm}$ (44.9 in) at Hope. At Fayetteville, the number of frost-free days from 2002 to 2005 was 192, 225, 247, and 209, respectively. At Hope, the number of growing days from 2002 to 2005 was $239,226,298$, and 222, respectively.

Tree height and trunk diameter were measured after planting in April 2002 at both locations and after the trees shed all

Table 2. Monthly average high temperature and monthly average low temperature at Fayetteville and Hope, Arkansas, from 2002 to 2005.

\begin{tabular}{|c|c|c|c|c|c|c|c|c|c|c|}
\hline \multirow[b]{2}{*}{ Month } & \multicolumn{2}{|c|}{$2002\left({ }^{\circ} \mathrm{C}\right)$} & \multicolumn{2}{|c|}{$2003\left({ }^{\circ} \mathrm{C}\right)$} & \multicolumn{2}{|c|}{$2004\left({ }^{\circ} \mathrm{C}\right)$} & \multicolumn{2}{|c|}{$2005\left({ }^{\circ} \mathrm{C}\right)$} & \multicolumn{2}{|c|}{ Average $^{\mathrm{z}}\left({ }^{\circ} \mathrm{C}\right)$} \\
\hline & High & Low & High & Low & High & Low & High & Low & High & Low \\
\hline \multicolumn{11}{|c|}{ Fayetteville } \\
\hline Feb. & 10 & -2 & 8 & -3 & 8 & -4 & 13 & 3 & 10 & -2 \\
\hline Mar. & 12 & 0 & 15 & 2 & 17 & 7 & 14 & 3 & 15 & 3 \\
\hline Apr. & 22 & 10 & 22 & 8 & 21 & 10 & 20 & 9 & 21 & 9 \\
\hline July & 31 & 22 & 31 & 20 & 28 & 19 & 32 & 20 & 31 & 20 \\
\hline Aug. & 32 & 21 & 32 & 19 & 28 & 18 & 33 & 21 & 31 & 19 \\
\hline Sept. & 29 & 16 & 24 & 12 & 29 & 15 & 31 & 18 & 28 & 15 \\
\hline Oct. & 18 & 10 & 21 & 8 & 22 & 12 & 23 & 10 & 20 & 10 \\
\hline Nov. & 13 & 2 & 13 & 3 & 16 & 7 & 18 & 5 & 14 & 4 \\
\hline Mar. & 16 & 3 & 18 & 4 & 21 & 8 & 18 & 5 & 18 & 5 \\
\hline Apr. & 24 & 12 & 24 & 9 & 21 & 4 & 24 & 9 & 23 & 8 \\
\hline May & 25 & 14 & 27 & 16 & 21 & 18 & 28 & 12 & 28 & 15 \\
\hline June & 31 & 18 & 28 & 18 & 31 & 21 & 32 & 18 & 30 & 19 \\
\hline July & 33 & 22 & 32 & 22 & 32 & 21 & 34 & 21 & 33 & 21 \\
\hline Aug. & 33 & 21 & 33 & 22 & 32 & 19 & 37 & 21 & 34 & 21 \\
\hline Sept. & 31 & 18 & 28 & 16 & 31 & 16 & 33 & 18 & 31 & 17 \\
\hline Oct. & 21 & 12 & 25 & 11 & 26 & 14 & 25 & 9 & 24 & 12 \\
\hline Nov. & 16 & 2 & 19 & 7 & 18 & 9 & 21 & 7 & 18 & 6 \\
\hline Dec. & 12 & 1 & 13 & -1 & 13 & -1 & 14 & -2 & 13 & 0 \\
\hline
\end{tabular}

${ }^{\mathrm{z}}$ The average is calculated based on the weather data from 2002 to 2005 . 
Table 3. Monthly precipitation at Fayetteville and Hope, Arkansas, from 2002 to 2005.

\begin{tabular}{|c|c|c|c|c|c|}
\hline \multirow[b]{2}{*}{ Month } & \multicolumn{5}{|c|}{ Precipitation $(\mathrm{cm})$} \\
\hline & 2002 & 2003 & 2004 & 2005 & Avg. ${ }^{2}$ \\
\hline \multicolumn{6}{|c|}{ Fayetteville } \\
\hline Jan. & 4.8 & 0.6 & 3.6 & 14.5 & 5.9 \\
\hline Feb. & 4.5 & 6.9 & 2.1 & 5.3 & 4.7 \\
\hline Mar. & 24.4 & 6.7 & 6.8 & 3.3 & 10.3 \\
\hline Apr. & 17.3 & 6.3 & 18.6 & 10.4 & 13.2 \\
\hline May & 13.2 & 15.0 & 2.7 & 9.4 & 10.1 \\
\hline June & 10.2 & 10.3 & 14.1 & 11.4 & 11.5 \\
\hline July & 2.2 & 8.9 & 21.2 & 4.6 & 9.2 \\
\hline Aug. & 15.8 & 4.2 & 2.1 & 4.8 & 6.7 \\
\hline Sept. & 1.5 & 8.4 & 1.5 & 7.4 & 4.7 \\
\hline Oct. & 5.6 & 11.7 & 8.7 & 0.8 & 6.7 \\
\hline Nov. & 2.6 & 10.7 & 18.1 & 6.0 & 8.3 \\
\hline Dec. & 12.7 & 4.8 & 3.9 & 1.0 & 5.6 \\
\hline Total & 114.8 & 94.4 & 103.4 & 79.0 & 97.9 \\
\hline \multicolumn{6}{|c|}{ Hope } \\
\hline Jan. & 7.4 & 1.2 & 9.7 & 13.5 & 7.9 \\
\hline Feb. & 4.6 & 21.5 & 11.6 & 7.4 & 11.3 \\
\hline Mar. & 20.9 & 4.3 & 12.5 & 7.4 & 11.3 \\
\hline Apr. & 5.1 & 6.3 & 17.2 & 8.4 & 9.2 \\
\hline May & 17.3 & 12.9 & 21.0 & 4.4 & 13.9 \\
\hline June & 1.0 & 17.6 & 9.8 & 4.7 & 8.3 \\
\hline July & 9.3 & 10.2 & 8.4 & 6.2 & 8.5 \\
\hline Aug. & 3.7 & 2.7 & 4.0 & 7.5 & 4.5 \\
\hline Sept. & 5.1 & 6.8 & 3.9 & 13.2 & 7.3 \\
\hline Oct. & 24.7 & 6.4 & 17.3 & 0 & 12.1 \\
\hline Nov. & 5.3 & 6.4 & 20.6 & 7.6 & 10.0 \\
\hline Dec. & 19.4 & 7.2 & 4.1 & 1.4 & 8.0 \\
\hline Total & 123.7 & 103.5 & 140.2 & 81.6 & 112.3 \\
\hline
\end{tabular}

${ }^{\mathrm{z}}$ The average is calculated based on the weather data from 2002 to 2005 .

leaves each fall (except 2005). Tree height was measured as the distance between the tallest bud on the tree and the soil surface. Trunk diameter was measured at $15 \mathrm{~cm}(6$ in) above the soil surface using a caliper. Year-end measurements were taken at Fayetteville and Hope on 29 and 17 October 2002, on 4 December and 13 November 2003, on 16 and 28 November 2004, and on 13 and 4 October 2005, respectively. Annual change, presented as a percentage, is defined as the change in tree height or trunk diameter between the fall of the previous year and the fall of the current year divided by the same growth parameter at the end of the previous growing season. For 2002 data, the change in growth is divided by the initial value at planting. Survival of each birch genotype was recorded annually.

Two trial locations were treated as two separate experiments. The experimental design was a completely randomized design consisting of a two-factor factorial of 16 genotypes (B. albosinensis and B. pendula 'Trost's Dwarf' did not survive through 2005 , and $B$. ermanii and $B$. lenta were not included in statistical analysis as a result of excessive mor- tality) $\times$ two irrigation regimes with seven to 15 replications at Fayetteville and a completely randomized design consisting of one factor of 13 genotypes with four to 12 replications at Hope (seven of 20 genotypes did not survive through 2005). Data were subjected to analysis of variance (ANOVA) in a General Linear Model using SAS software (version 9.1, 2004; SAS Institute Inc., Cary, NC). Means were considered significantly different if $P$ value was less than 0.05 or 0.1 as determined by ANOVA.

\section{RESULTS}

\section{Fayetteville}

The overall tree survival was $62 \%$ (Table 4). The average survival for WW trees and WS trees was 64\% and 59\%, respectively. Survival after four growing seasons ranged from $100 \%$ (B. $\times$ 'Royal Frost') to 0\% (B. albosinensis and B. pendula 'Trost's Dwarf'). Genotypes, which had greater than 90\% survival, also included B. nigra 'BNMTF' Dura-Heat ${ }^{\mathrm{TM}}$ (93\%), B. nigra 'Cully' (94\%), B. pendula 'Laciniata' (93\%), and B. populifolia $(93 \%)$.

There was an interaction between genotype and irrigation on the tree height in 2005 (Table 5). Main effects of genotype and irrigation treatment were significant. The WS treatment

Table 4. Survival of 20 birch genotypes evaluated at Fayetteville ${ }^{z}$ and Hope ${ }^{y}$, Arkansas, in 2005.

\begin{tabular}{|c|c|c|c|c|}
\hline \multirow[b]{2}{*}{ Genotype } & \multicolumn{2}{|c|}{ Fayetteville } & \multicolumn{2}{|c|}{ Hope } \\
\hline & $\begin{array}{l}\text { No. of } \\
\text { trees }\end{array}$ & $\begin{array}{l}\text { Survival } \\
(\%)\end{array}$ & $\begin{array}{l}\text { No. of } \\
\text { trees }\end{array}$ & $\begin{array}{l}\text { Survival } \\
(\%)\end{array}$ \\
\hline B. albosinensis & 14 & 0 & 6 & 0 \\
\hline B. pendula 'Trost's Dwarf' & 14 & 0 & 6 & 0 \\
\hline B. ermanii & 14 & 7 & 6 & 0 \\
\hline B. lenta & 14 & 14 & 6 & 50 \\
\hline B. maximowicziana & 14 & 29 & 6 & 17 \\
\hline B. alleghaniensis & 14 & 36 & 6 & 0 \\
\hline B. utilis var. jacquemontii & 14 & 36 & 6 & 0 \\
\hline B. platyphylla 'Fargo' & 18 & 44 & 6 & 17 \\
\hline B. papyrifera & 19 & 68 & 6 & 17 \\
\hline B. davurica & 14 & 71 & 6 & 17 \\
\hline B. nigra & 28 & 75 & 12 & 17 \\
\hline B. papyrifera 'Renci' & 14 & 79 & 4 & 0 \\
\hline B. papyrifera 'Uenci' & 14 & 79 & 4 & 50 \\
\hline B. populifolia 'Whitespire' & 14 & 79 & 6 & 33 \\
\hline B. pendula & 29 & 83 & 12 & 17 \\
\hline B. nigra 'BNMTF' & 14 & 93 & 6 & 100 \\
\hline B. pendula 'Laciniata' & 14 & 93 & 6 & 0 \\
\hline B. populifolia & 14 & 93 & 6 & 83 \\
\hline B. nigra 'Cully' & 30 & 94 & 12 & 92 \\
\hline B. $\times$ 'Royal Frost' & 14 & 100 & 4 & 75 \\
\hline Average & - & 62 & - & 30 \\
\hline
\end{tabular}

${ }^{\mathrm{z}}$ Trees were exposed to two irrigation regimes at Fayetteville since 2003.

${ }^{y}$ All trees were irrigated at Hope. 
Table 5. Statistical significance from analysis of variance of genotype and irrigation treatment on the initial and final tree height and trunk diameter of birch trees planted in Spring $\mathbf{2 0 0 2}$ at Fayetteville and Hope, Arkansas. ${ }^{2}$

\begin{tabular}{lllll}
\hline & \multicolumn{3}{c}{ Statistical significance $(P$ value $)$} & Hope \\
\cline { 2 - 3 } \cline { 3 - 4 } Source & Genotype $\times$ irrigation & Genotype & Irrigation & Genotype \\
\hline Initial tree height & 0.4381 & 0.0001 & 0.5030 & 0.0030 \\
Initial trunk diameter & 0.4348 & 0.0001 & 0.0608 & 0.0014 \\
Final tree height & 0.0236 & 0.0001 & 0.0001 & 0.0001 \\
Final trunk diameter & 0.3838 & 0.0001 & 0.0005 & 0.0001 \\
$\mathrm{AC}_{2002}$ in tree height & 0.2849 & 0.0001 & 0.2334 & 0.0939 \\
$\mathrm{AC}_{\text {2002 }}$ in trunk diameter & 0.4733 & 0.0001 & 0.3059 & 0.0001 \\
$\mathrm{AC}_{\text {2003 }}$ in tree height & 0.9972 & 0.0001 & 0.3682 & 0.0001 \\
$\mathrm{AC}_{\text {2003 }}$ in trunk diameter & 0.3816 & 0.0001 & 0.6797 & 0.0020 \\
$\mathrm{AC}_{2004}$ in tree height & 0.1815 & 0.0008 & 0.4559 & 0.0034 \\
$\mathrm{AC}_{2004}$ in trunk diameter & 0.2585 & 0.0001 & 0.1177 & 0.0001 \\
$\mathrm{AC}_{\text {2005 }}$ in tree height & 0.1290 & 0.0001 & 0.0009 & 0.0681 \\
$\mathrm{AC}_{\text {2005 }}$ in trunk diameter & 0.2119 & 0.0001 & 0.0001 & 0.5204 \\
\hline
\end{tabular}

${ }^{\mathrm{z}}$ Final measurements were taken in Fall 2005.

reduced tree height (data not shown). Of those genotypes that survived, B. nigra 'Cully', B. nigra 'BNMTF', $B . \times$ 'Royal Frost', $B$. nigra, and $B$. pendula 'Laciniata' were among the tallest trees in the plot (Figure 1). Only B. nigra was among the genotypes with the greatest annual change in tree height during every growing season from 2002 to 2005 (data not shown). In both 2004 and 2005, B. davurica was also among the genotypes with the greatest annual change in tree height. Betula utilis var. jacquemontii was the shortest tree and had the lowest annual change in tree height in both 2004 and 2005 . The overall average annual change in height was $169 \%$, $117 \%, 59 \%$, and $23 \%$ from 2002 to 2005 .

No interaction between birch genotypes and irrigation regimes was observed for the final trunk diameter (Table 5).

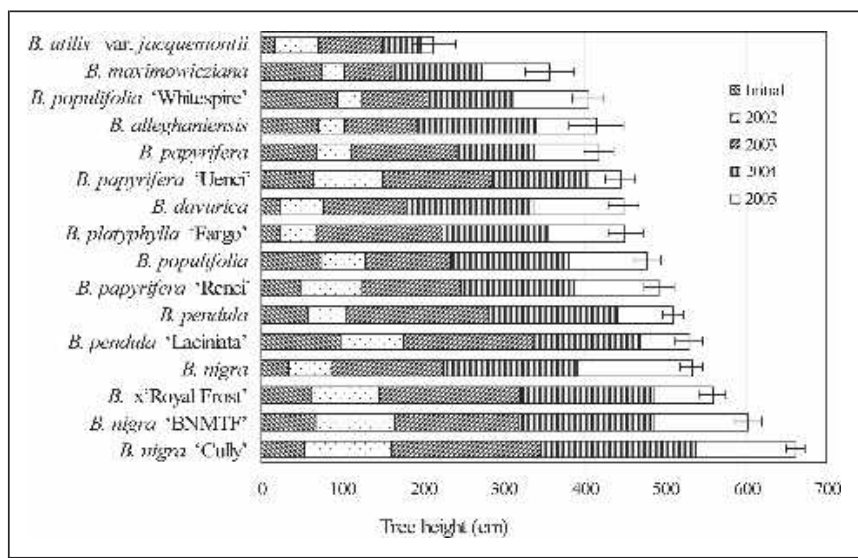

Figure 1. Tree height of birch trees at Fayetteville, Arkansas, from 2002 to 2005 . Bars represent standard error of genotype on the final tree height (Tukey's adjusted test; $P \leq$ 0.05).
Main effects of genotype and irrigation treatment were significant for final trunk diameter. The WS treatment reduced trunk diameter in birch trees (data not shown). Of the surviving birch genotypes, $B$. nigra and its two selections, 'BNMTF' and 'Cully', had greater final trunk diameter than B. utilis var. jacquemontii, B. populifolia 'Whitespire', $B$. papyrifera 'Uenci' Renaissance Upright ${ }^{\mathrm{TM}}$, B. papyrifera, $B$. platyphylla 'Fargo' Dakota Pinnacle ${ }^{\mathrm{TM}}$, B. alleghaniensis, and B. maximowicziana (Figure 2). In 2005, B. nigra, B. nigra 'BNMTF', B. davurica, and B. platyphylla 'Fargo' had the greatest annual change in trunk diameter, and $B$ papyrifera 'Uenci', B. pendula 'Laciniata', and B. $\times$ 'Royal Frost' had the lowest annual change in trunk diameter (data not shown). The overall average annual change in trunk diameter

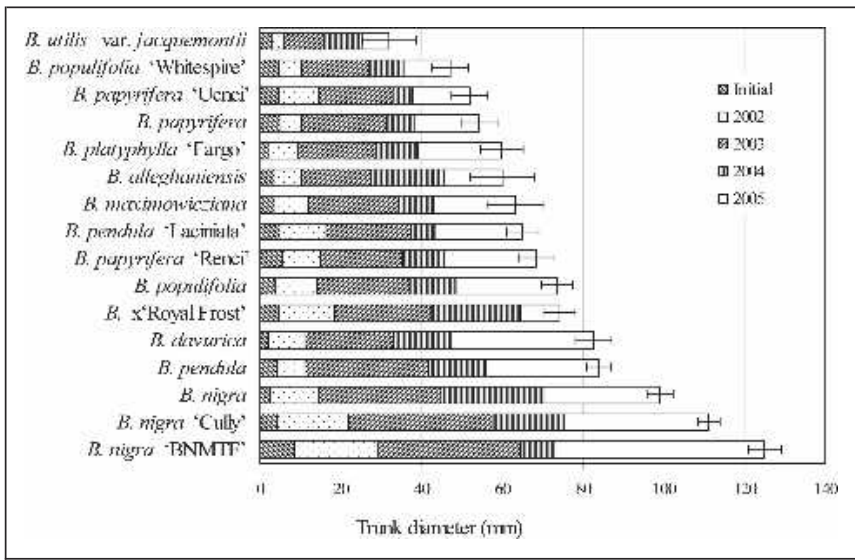

Figure 2. Trunk diameter of birch trees at Fayetteville, Arkansas, from 2002 to 2005 . Bars represent standard error of genotype on the final trunk diameter (Tukey's adjusted test; $P \leq 0.05$ ). 
was $276 \%, 181 \%, 52 \%$, and $29 \%$, respectively, from 2002 to 2005.

\section{Hope}

The tree survival by the end of 2005 was $30 \%$ (Table 4). Seven of 20 birch genotypes (B. albosinensis, B. alleghaniensis, B. ermanii, B. papyrifera 'Renci' Renaissance Reflection $^{\mathrm{TM}}$, B. pendula 'Trost's Dwarf', B. pendula 'Laciniata', and $B$. utilis var. jacquemontii) did not survive through four growing seasons. Six of 13 survived birch genotypes died back in 2002 (Figure 3). Survival of the 13 genotypes ranged from $17 \%$ (B. davurica, B. maximowicziana, B. nigra, B. pendula, and B. platyphylla 'Fargo') to $100 \%$ (B. nigra 'BNMTF'). Betula nigra 'Cully' (94\%) was the only other genotype, which had greater than $90 \%$ survival.

There were significant differences for final tree height, final trunk caliper, and annual annual change among genotypes (Table 5). Of the 13 surviving genotypes, $B$. nigra 'Cully', B. nigra 'BNMTF', B. × 'Royal Frost', B. pendula, and $B$. papyrifera were significantly taller than $B$. papyrifera 'Uenci', B. populifolia 'Whitespire', B. maximowicziana, and $B$. lenta after four growing seasons (Figure 3). In both 2004 and $2005, B$. papyrifera was among trees with the highest annual change in tree height, and one of its selections, 'Uenci', had the lowest annual change in tree height (data not shown). The overall average annual change in height was $56 \%, 151 \%, 40 \%$, and $26 \%$ from 2002 to 2005.

Betula nigra 'Cully', B. nigra 'BNMTF', and B. pendula had greater final trunk diameter than B. papyrifera 'Uenci', B. populifolia 'Whitespire', B. nigra, B. maximowicziana, and B. lenta (Figure 4). In 2004, B. davurica and B. papyrifera had the highest annual change in trunk diameter and $B$. papyrifera 'Uenci' had the lowest annual change (data not shown). In 2005, annual change in trunk diameter was not significant among the birch genotypes (Table 5). The overall

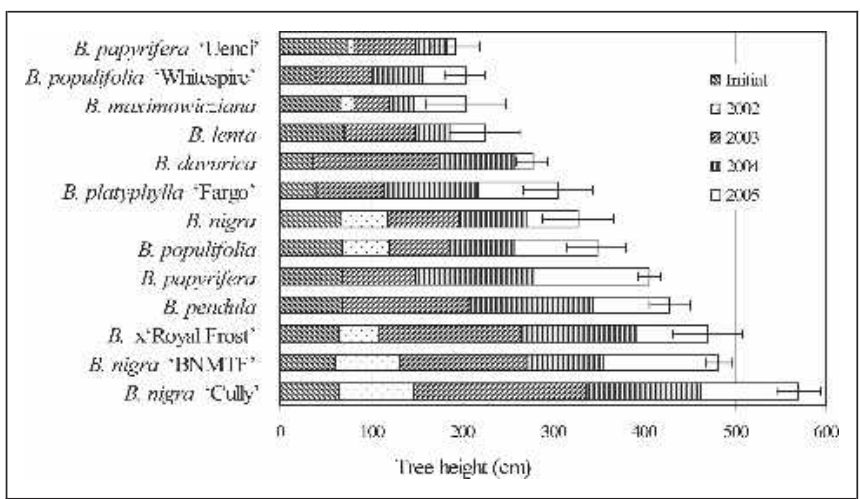

Figure 3. Tree height of birch trees at Hope, Arkansas, from 2002 to 2005. Bars represent standard error of genotype on the final tree height (Tukey's adjusted test; $\boldsymbol{P} \leq$ 0.05).

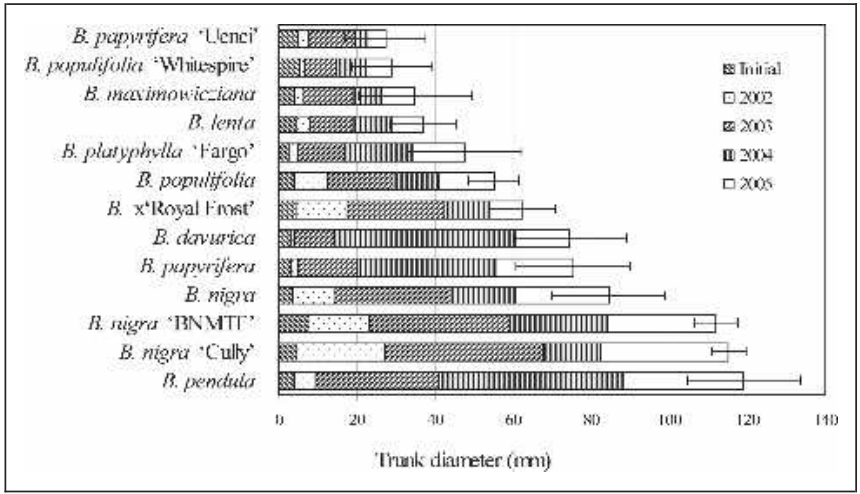

Figure 4. Trunk diameter of birch trees at Hope, Arkansas, from 2002 to 2005. Bars represent standard error of genotype on the final trunk diameter (Tukey's adjusted test; $P \leq$ 0.05).

average annual change in trunk diameter was $169 \%, 196 \%$, $79 \%$, and $31 \%$ from 2002 to 2005 .

\section{DISCUSSION}

Hope is located at a lower latitude and lower elevation than Fayetteville and in a different USDA cold hardiness zone and AHS heat zone. Both monthly average high temperatures and monthly average low temperatures were higher at Hope than Fayetteville from 2002 to 2005 (Table 1). The warmer temperature at Hope may account for the lower overall survival compared with Fayetteville (Table 4). Only $41 \%$ of birch trees survived through the first growing season at Hope compared with $86 \%$ at Fayetteville. The warmer temperature may also increase transpiration, which exceeded water uptake capacity from the establishing root system and led to shoot dieback in six birch genotypes at Hope in 2002. The survival changed slightly after 2003, which could be attributed by initial screening in the first 2 years and the established root systems in survived trees.

In 2003 and 2004, most birch trees had greater growth in both height and trunk caliper at two locations than in 2002 (Figures 1-4), which could be attributed to more established roots. Although there was more rainfall in 2004, the relatively cool summer in Fayetteville could result in less growth in trunk diameter (Figure 2).

Betula pendula 'Trost's Dwarf', B. ermanii, and B. albosinensis had the lowest survival at both locations in $\mathrm{Ar}$ kansas after four growing seasons (Table 4). Dirr (1998) found that Betula pendula 'Trost's Dwarf' did not perform as well in the landscapes as indicated by articles, and B. ermanii was rarely seen in the eastern United States as a result of high temperature. Betula populifolia, B. nigra 'BNMTF', B. nigra 'Cully', and $B . \times$ 'Royal Frost' had greater survival than the other birch genotypes investigated at both locations. One unexpected results was the low survival of B. nigra at both 
locations. One possible explanation is the provenance sources for the seed-grown $B$. nigra seedlings.

Experiments under controlled conditions indicated that water-deficit stress reduced tree height of birch genotypes (Fort et al. 1998; Pääkkönen et al. 1998; Wang et al. 1998). Similar reductions were observed for most birch trees investigated under the field conditions at Fayetteville (data not shown). Betula populifolia 'Whitespire' was reported to be better adapted to dry sites than B. nigra, B. maximowicziana, $B$. papyrifera, $B$. pendula, and B. populifolia in a study under controlled conditions (Ranney et al. 1991). However, its growth was among the lowest at Fayetteville (Figures 1 and 2 ), and the difference between the growth of WW plants and WS plants was not significant (data not shown). Dirr's (1998) observation at a nursery indicated that 'Cully' was superior in every aspect when compared with 'Whitespire'.

\section{CONCLUSION}

Based on the tree survival, growth, and annual change of the 20 birch genotypes, $B$. nigra 'Cully', $B . \times$ 'Royal Frost', $B$. pendula, $B$. nigra 'BNMTF', $B$. davurica, and $B$. papyrifera could survive and be used for landscape use in the southern United States. Betula pendula 'Trost's Dwarf', B. ermanii, $B$. albosinensis, B. populifolia 'Whitespire', B. papyrifera 'Uenci', B. lenta, B. maximowicziana, B. utilis var. jacquemontii, and $B$. alleghaniensis would not perform well in landscapes in the southern United States.

Of the six birch genotypes recommended for the southern United States, Betula nigra 'Cully', B. nigra 'BNMTF', and $B$. davurica have creamy white to reddish brown peeling bark. Betula $\times$ 'Royal Frost', B. pendula, and B. papyrifera have distinguished white bark. Leaves on $B . \times$ 'Royal Frost' are burgundy red in spring and the color fades off slightly during summer, and turned to red or orange-red in the fall. The other five genotypes have yellow fall foliage. All six genotypes have pyramidal habit and could be used as specimen or shade tree in the landscape.

Acknowledgments. We thank Manjula Carter for technical assistance at the Southwest Research and Extension Center, Hope, AR, and for financial assistance from the Research Incentive Grant Program at the University of Arkansas.

\section{LITERATURE CITED}

Atkinson, M.D. 1992. Betula pendula Roth (B. verrucosa Ehrh.) and B. pubescens Ehrh. Journal of Ecology 80: 837-870.

Dirr, M.A. 1998. Manual of woody landscape plants: Their identification, ornamental characteristics, culture, propagation and uses. 5th ed. Stipes Publishing L.L.C., Champaign, IL.
Farrar, J.L. 1995. Trees of the northern United States and Canada. 1st ed. Iowa State University Press, Ames, IA.

Fort, C., F. Muller, P. Label, A. Granier, and E. Dreyer. 1998. Stomatal conductance, growth and root signaling in Betula pendula seedlings subjected to partial soil drying. Tree Physiology 18:769-776.

Furlow, J.J. 1990. The genera of Betulaceae in the southeastern United States. Journal of the Arnold Arboretum 71: $1-67$.

Krussmann, G. 1984. Manual of cultivated broad-leaved trees and shrubs. 1st ed. Timber Press, Beaverton, OR.

Ladjal, M., D. Epron, and M. Ducrey. 2000. Effect of water deficit preconditioning on thermotolerance of photosystem II and susceptibility of photosynthesis to heat stressing cedar seedlings. Tree Physiology 20:1235-1241.

Pääkkönen, E., J. Vahala, M. Pohjolai, T. Holopainen, and L. Kärenlampi. 1998. Physiological, stomatal and ultrastructural ozone responses in birch (Betula pendula Roth.) are modified by water stress. Plant, Cell \& Environment 21: 671-684.

Ranney, T.G., R.E. Bir, and W.A. Skroch. 1991. Comparative water deficit resistance among six species of birch (Betula): Influence of mild water stress on water relations and leaf gas exchange. Tree Physiology 8:351-360.

Ranney, T.G., and M.M. Peet. 1994. Heat tolerance of five taxa of birch (Betula): Physiological responses to supraoptimal leaf temperatures. Journal of the American Society for Horticultural Science 119:243-248.

Santamour, F.S. Jr. 1999. Progress in the development of borer-resistant white-barked birches. Journal of Arboriculture 25:151-162.

Santamour, F.S. Jr., and L.N. Lundgren. 1997. Rhododendrin in Betula: A reappraisal. Biochem. Systemat. Ecol. 25: 335-341.

Wang, J.R., C.D.B. Hawkins, and T. Letchford. 1998. Relative growth rate and biomass allocation of paper birch (Betula papyrifera) populations under different soil moisture and nutrient regimes. Canadian Journal of Forest Research 28:44-55.

Zwack, J.A., and W.R. Graves. 1998. Leaf water relations and plant development of three freeman maple cultivars subjected to water deficit. Journal of the American Society for Horticultural Science 123:371-375.

Mengmeng $G u$ (corresponding author)

(formerly) Department of Horticulture

University of Arkansas

Fayetteville, AR 72701, U.S.

(currently) Department of Plant and Soil Sciences

Mississippi State University

PO Box 9555

Mississippi State, MS 39762, U.S.

mgu@pss.msstate.edu 
James A. Robbins

Cooperative Extension Service

Department of Horticulture

University of Arkansas

Little Rock, AR 72203, U.S.

Curt R. Rom

Department of Horticulture

University of Arkansas

Fayetteville, AR 72701, U.S.

Résumé. Vingt génotypes de bouleaux ont été planté en champ en avril 2002 pour évaluer leur taux de survie et de croissance à Fayetteville et Hope en Arkansas, et aussi pour évaluer leur réponse en regard de deux régimes différents d'irrigation à Fayetteville. Après quatre saisons de croissance, le taux global de survie des arbres était de $62 \%$ et 30\% respectivement à Fayetteville et Hope. Betula pendula 'Trost's Dwarf', B. ermanii et B. albosinensis comptaient parmi les génotypes avec les plus faibles taux de survie aux deux endroits. Betula populifolia, B. nigra 'BNMTF', B. nigra 'Cully' et $B . \times$ 'Royal Frost' avaient les plus hauts taux de survie après quatre saisons de croissance par rapport aux autres génotype testés. Betula nigra 'BNMTF' et $B$. nigra 'Cully' étaient plus grands et avaient un plus fort calibre de tronc que les autres génotypes de bouleaux aux deux endroits après quatre saisons de croissance. À la fin de 2005 , B. utilis var. jacquemontii était le plus petit et avait le plus calibre de tronc le plus faible parmi les 18 génotypes ayant survécus à Fayetteville, et $B$. papyrifera 'Uenci' ainsi que $B$. populifolia 'Whitespire', B. maximowicziana et $B$. lenta étaient les plus petits et avaient les plus calibres de tronc les plus faibles parmi les 18 génotypes ayant survécus à Hope. À Fayetteville, B. nigra et B. davurica avaient les plus grands changements annuels quant à la croissance en hauteur à la fois en 2004 et en 2005, tandis que $B$. davurica était parmi les génotypes qui avaient les plus grands changements annuels de calibre de tronc en 2002, 2004 et 2005. À Hope, B. papyrifera avait les plus grands changements annuels quant à la croissance en hauteur à la fois en 2004 et en 2005, tandis que B. davurica avait les plus grands changements annuels de calibre de tronc en 2004. En 2005, le changement annuel n'était pas significatif parmi les génotypes de bouleaux à Hope. À Fayetteville, le traitement lié à limitation de l'irrigation a diminué la hauteur et le calibre final des troncs chez les bouleaux.

Zusammenfassung. Zwanzig Birken-Genotypen wurden im April 2002 in Feldversuchen ausgepflanzt, um ihr Überleben und Wachstum in Fayetteville und Hope, Arkansas zu bewerten, und ihre Reaktion auf zwei Bewässerungssysteme in Fayetteville zu bewerten. Nach vier Wachstumsperioden war die Überlebensrate $62 \%$ und $30 \%$ in Fayetteville und Hope. Betula pendula Trosts Dwarf, $B$. ermanii und $B$. albosinensis waren die Genotypen mit der niedrigsten Überlebensrate an beiden Standorten. B. populifolia, B. nigra BNMTF, B. nigra Cully und B. $\times$ Royal Frost hatten nach vier Wachstumsperioden ein stärkeres Überleben als die anderen untersuchten Genotypen. B. nigra BNMTF und B. nigra Cully waren nach vier Wachstumsperioden an beiden Standorten größer und einen größeren Stammdurchmesser als die andern überlebenden Genotypen. Am Ende von 2005 war B. utilis var. jacquemontii die kleinste und dünnste Birkenart von 18 überlebenden Genotypen in Fayetteville und B. papyrifera Uenci, B. populifolia Whitespire, $B$. maximowicziana und $B$. lenta waren die kürzesten und dünnsten Birken von 13 überlebenden Genotypen in Hope. 2004 und 2005 hatten in Fayetteville B. nigra und B. davurica den größten jährlichen Höhenzuwachs und $B$. davurica war unter den Genotypen mit dem größten jährlichen Dickenzuwachs in den Jahren 2002, 2004 und 2005. In Hope hatte B. papyrifera den größten jährlichen Höhenzuwachs in 2004 und 2005 und B. davurica hatte den größten jährlichen Dickenzuwachs in 2004. In 2005 war der jährliche Zuwachs unter allen Genotypen in Hope nicht signifikant. In Fayetteville begrenzte der Wasserstress unter der Behandlung die Baumhöhe und den Dickenzuwachs bei den Birken.

Resumen. Se plantaron 20 genotipos de abedul en Abril de 2002 para evaluar su supervivencia y crecimiento en Fayetteville y Hope, Arkansas; y valorar su respuesta a dos regímenes de riego en Fayetteville. Después de cuatro estaciones de crecimiento, la supervivencia total fue $62 \%$ y $30 \%$ en Fayetteville y Hope, respectivamente. Betula pendula 'Trost's Dwarf', B. ermanii, y B. albosinensis estuvieron entre los genotipos con la supervivencia más baja en ambas localidades. Betula populifolia, B. nigra 'BNMTF', B. nigra 'Cully', y $B . \times$ 'Royal Frost' tuvieron mayor supervivencia después de cuatro estaciones de crecimiento que los otros genotipos investigados de abedul. Betula nigra 'BNMTF' y B. nigra 'Cully'fueron árboles más altos y tuvieron mayores diámetros del tronco que los otros genotipos en las dos localidades después de las cuatro estaciones de crecimiento. Al final del 2005, B. utilis var. jacquemontii fue el árbol más pequeño y tuvo el diámetro del tronco más pequeño entre los 18 genotipos que sobrevivieron en Fayetteville; y $B . p a$ pyrifera 'Uenci', B. populifolia 'Whitespire', B. maximowicziana, y $B$. lenta tuvieron el más corto y el más pequeño diámetro del tronco entre los 13 genotipos sobrevivientes en Hope. En Fayetteville, $B$. nigra y $B$. davurica tuvieron el mayor cambio anual en altura del árbol tanto en 2004 como en 2005, y B. davurica estuvo entre los genotipos con el mayor cambio anual en diámetro del tronco en 2002, 2004 y 2005. En Hope, B. papyrifera tuvo el mayor cambio anual en altura en 2004 y 2005, y B. davurica tuvo el mayor cambio anual en diámetro del tronco en 2004. En 2005, el cambio anual no fue significativo entre los genotipos en Hope. En Fayetteville, los tratamientos de estrés hídrico redujeron la altura final y el diámetro del tronco en los árboles de abedul. 